\title{
LE CORBUSIER, THE CITY, AND THE MODERN UTOPIA OF DWELLING
}

\author{
Armando RABAÇA \\ Department of Architecture of the University of Coimbra, \\ Ed. Colégio das Artes, Largo D. Dinis, 3000-143 Coimbra \\ E-mail:rabaca@darq.uc.pt
}

Received 12 November 2015; accepted 22 April 2016

\begin{abstract}
In Le Corbusier's urban plans, the conventional public space of the city is gradually dismembered until it coalesces with the natural surroundings, giving rise to the concept of tapis-vert. Its ultimate expression is found in the Athens Charter. By investigating Le Corbusier's formative years, this article aims to clarify issues of form and meaning involved in this process. The focus on this early period reveals that the territorial scale of the alliance between city and nature is a central theme of Le Corbusier's concerns with urban planning, preceding the influence of Latin America in the 1930s which is often seen as its underlying momentum. The focus on form and meaning reveals the inextricable links between this alliance and Le Corbusier's existential idea of unity. The tapis vert of the Athens Charter will thus be seen as a conceptual argument of the holistic world-view of Le Corbusier's urban visions: the binding element of meaningful architectural forms and natural world ultimately rooted in his attempt to realize the modern utopia of dwelling.
\end{abstract}

Keywords: Le Corbusier, modern city, public space, urban landscape, urban form, Athens Charter, tapis vert, unity.

\section{Introduction}

The radical contribution of Le Corbusier's urban visions lies in the dismemberment of the city, subverting conventional urban spaces and disrupting the traditional duality between private and public space. The rue intérieur replaces the rue-corridor, with facilities and leisure activities relocated to the interior and roof-terraces of housing blocks. On the exterior, urban space is gradually transformed into a park, eventually coalescing with the natural surroundings (landscape, in short). The immeublevillas and horizontal blocks à redents of the Ville Contemporaine and Ville Radieuse take the debate on the garden city one step further (Figs 1-4), with broad alignments still resonating with the notion of rue corridor, despite the change in scale and greenery. In the later schemes of the Athens Charter, as in the plans for Nemours, La Rochelle, SaintDié, Meaux, and Marseilles, the tapis vert becomes a boundless entity through which the city merges with the territory (Figs 5, 6).

Thus understood, the tapis vert can be seen as a conceptual argument through which Le Corbusier

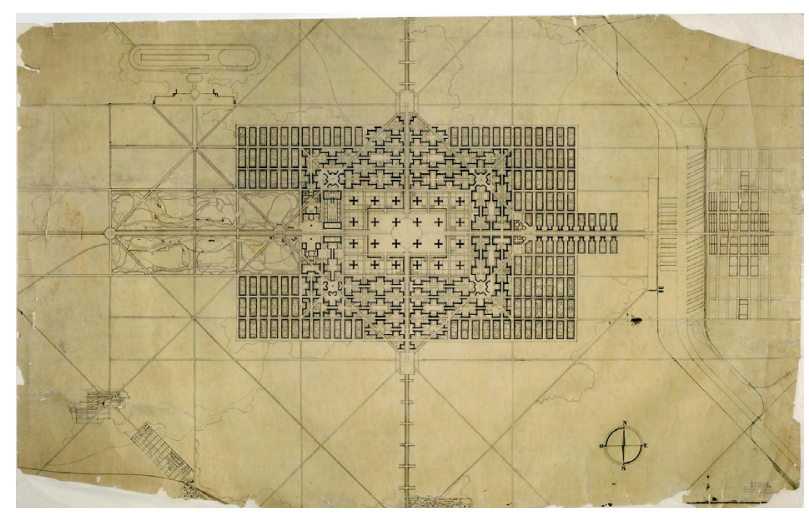

Fig. 1. Le Corbusier. Plan of the Ville Contemporaine, 1922. (oFLC

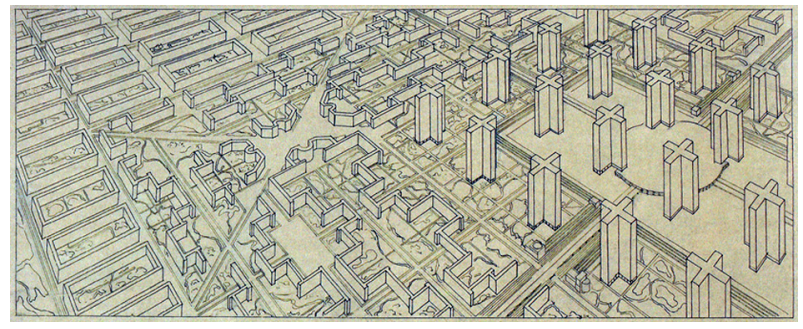

Fig. 2. Le Corbusier. Ville Contemporaine, 1922. CFLC 
pursues his search for a holistic alliance between city and natural world. This article is an elaboration of this proposition, in which the aim is to search for continuity and the evolutionary process underlying the gradual formulation of the city/landscape binomial in Le Corbusier's theoretical plans. The aims are essentially twofold: to investigate the background from which Le Corbusier came to conceptualize the idea of unity in the Athens Charter urban scheme, and to propose that the meaning he attributed to it is embedded in, and runs parallel to, this conceptualization. It therefore looks back on his formative years, where the essential earlier intuitions underlying his urban plans can be found. For the sake of brevity, the article focuses on three episodes from his study trips in order to discuss the city/landscape binomial in terms of form and meaning. In recognizing these elemental intuitions in the gradual formulation of the alliance between city and natural world in Le Corbusier's urban plans, it draws on Tafuri's penetrating essay Machine et Memoire (1987) and his view of Le Corbusier's urban plans from the 1940s onwards as a renunciation of the acts of cosmic refoundation and unity in his earlier plans. From this, the tapis vert of the Athens Charter emerges as the logical conclusion of Le Corbusier's attempt to realize the modern utopia of dwelling in harmony with the world.

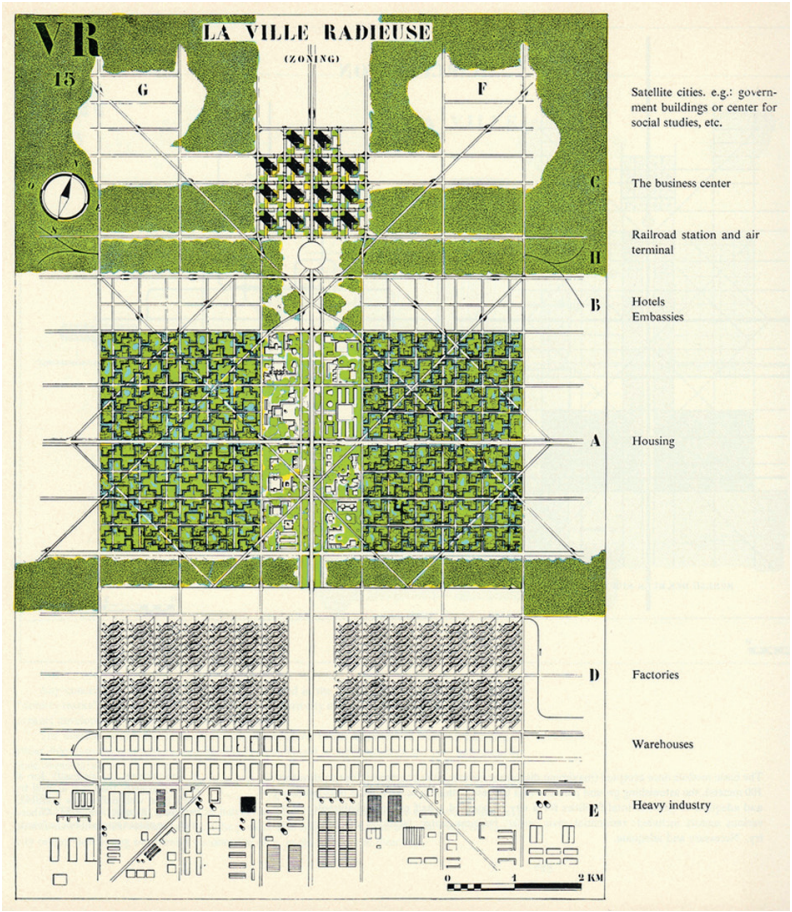

Fig. 3. Le Corbusier. Plan of the Ville Radieuse. From The Radiant City (1935). @FLC

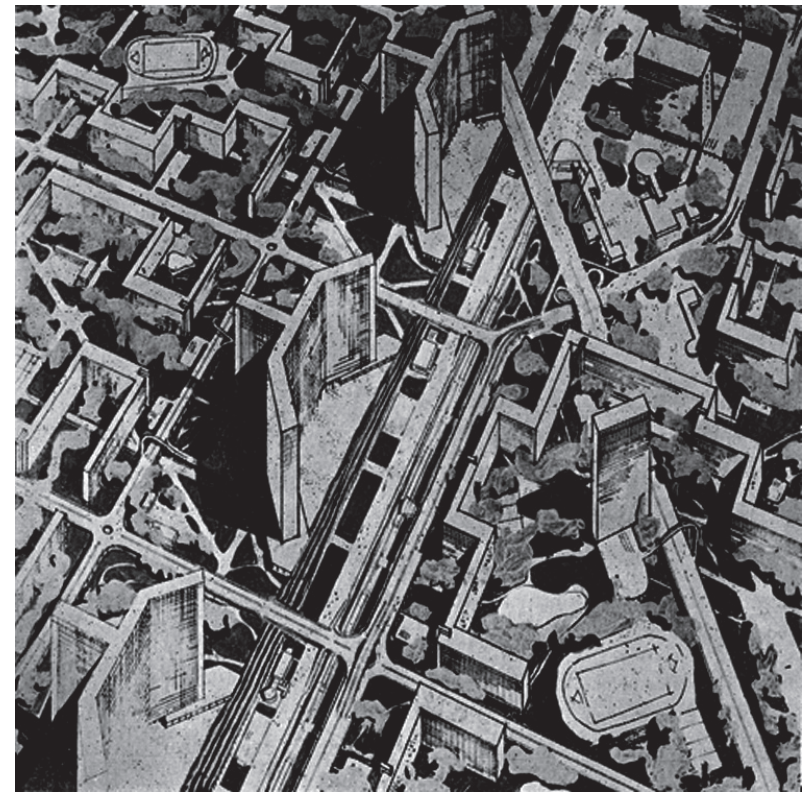

Fig. 4. Le Corbusier. The Ville Radieuse. From The Radiant City (1935). OFLC

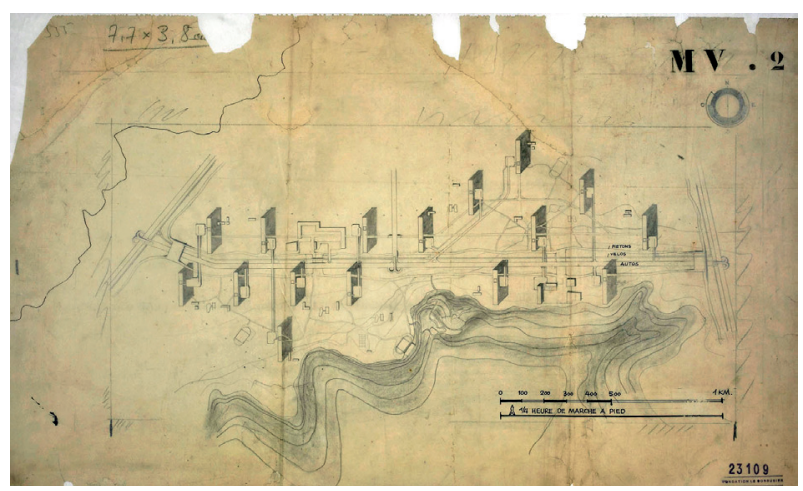

Fig. 5. Le Corbusier. Plan for Marseilleveyre, 1945. OFLC

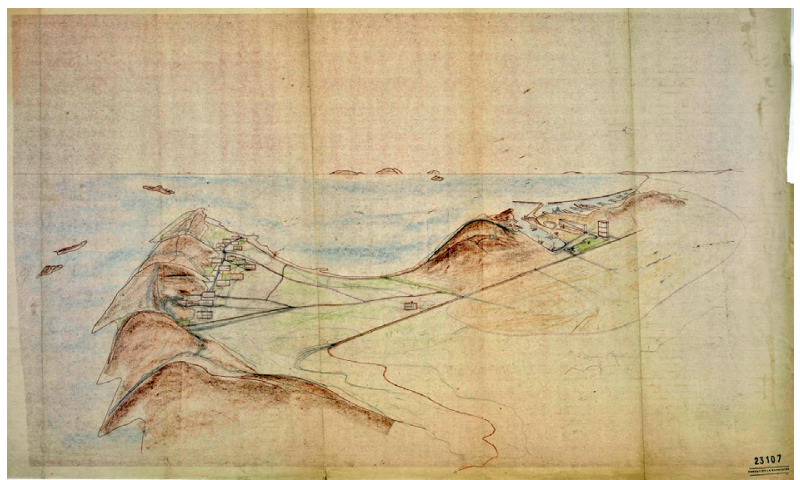

Fig. 6. Le Corbusier. Plan for Marseilleveyre, 1946. CFLC 


\section{The Monastery of Ema and Le Corbusier's housing blocks}

The first link between Le Corbusier's education and his later urban visions can be found in his 1907 visit to the Carthusian Monastery of Il Galluzzo in val d'Ema, near Florence (Ema, in short). The cells are the most distinctive feature of the Carthusian typology: two-storey dwelling units, each with a private walled garden, linked by the continuous gallery of the cloister. This visit has been discussed at length since Peter Serenyi (1967) noted its crucial role in Le Corbusier's later research into the modern dwelling. Le Corbusier himself acknowledged on several occasions how this visit had led him to the immeuble-villas and the unités d'habitation. Rather than on the individual/collective binomial and its links with the theories of Charles Fourier, this article focuses on the role of the landscape in Le Corbusier's experience.

Francesco Passanti (2010), on whose work this essay partially draws, has shown that the most intense experiences offered by the 1907 trip to Tuscany were bound together by the importance of the landscape in his architectural emotions: a mythical landscape associated with a legendary image of Italy, influenced by Rousseau's notion of origins and the significance of landscape in Le Corbusier's early education at La Chaux-de-Fonds. Although Le Corbusier was not capable of accurately formulating these emotions in architectural terms, they entailed latent intuitions that would develop into key aspects of his later work. This was the case of the Monastery of Ema, where the tension between the view of the landscape from the upper level of the monks' cells and the contrasting enclosed garden on the lower level (Fig. 7) led Le Corbusier to see architecture as a filter mediating between man and the landscape, a view later expressed in the apartments of the immeuble-villas.

In considering a unified modern society in the light of monasticism, Le Corbusier thus sensed a com-

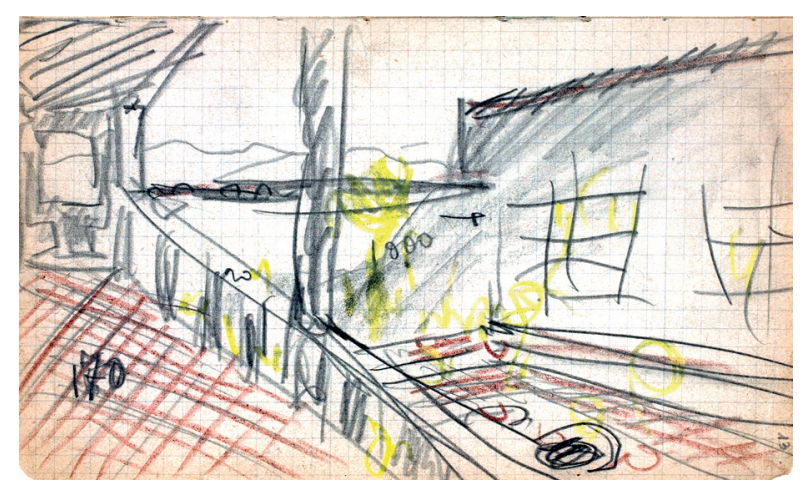

Fig. 7. Le Corbusier. Monastery of Ema. Sketchbook 6 of the journey to the East, 1911. @FLC plementary relationship between architecture and landscape. What was the nature of this relationship?

The parallel between monastic and modern life suggests a spiritual realm, and there is evidence that Le Corbusier invested the landscape itself with existential meaning. On the way to Florence, Le Corbusier had visited the monastery of Pavia, which belongs to the same Carthusian typology. The role of the landscape in his reading of the monasteries surfaces in a letter to his parents (2011: 37):

"I found there the solution for the unique typology for working class housing. Only the landscape will be hard to find ... my admiration was the same at the monastery of Pavia and I was able to convince myself that if they had renounced the world, they at least knew how to provide themselves with a delightful life, and I was persuaded that, in the end, it is mainly those who have a view of the Paradise who are the happy ones!"

Beyond indicating that Le Corbusier saw the Carthusian typology and its relation with the surrounding nature as the basis for an ideal, communal life, this passage also suggests that his preference for Ema (to where he returned after the journey to the East and which he repeatedly mentioned as a decisive influence on his housing design) is explained by the differences of the surrounding landscape. Whereas the monastery of Pavia lies in the middle of a vast plain, the monastery of Ema provides a view over the paradise by standing on top of a hill surrounded by undulating fields bounded by the distant Apennine Mountains. Here Le Corbusier found the two poles of the aesthetic theory of the beautiful and the sublime, with which he was familiar from reading authors such as John Ruskin and Charles Blanc (Passanti 2010: 26). The Apennines provided the sublime, the grandeur of nature and its indifference to man, human order, or worldly things - in short, a hint of the divine. The undulating fields provided the mythical original existence associated with the Romantic imagery of ancient Mediterranean civilizations, the tameable landscape delicately ordered by the work of man: Goethe's das Land wo die Zitronen blühen (the land where the lemon-trees flourish), as Passanti (2010) put it or, in Le Corbusier's words (1991: 91), a "musical landscape." It was this meaningful landscape that made Ema a place (Petit 1970: 44).

Through his Romantic education at La Chauxde-Fonds, Le Corbusier's idea of a paradisiacal life was associated with the imagery of an original relationship with nature. Beyond the issue of communal life, Ema provided him with a solution to the 
dichotomy between "la ville laide" (the ugly town) of La Chaux-de-Fonds (Le Corbusier 2011: 253) and the surrounding landscape of Pouillerel in two ways. First, architecture mediates between man and the landscape, that is, the landscape participates in the dwelling experience of each cell. Second, the association between the imagery of Mediterranean landscape and the idea of a primeval existence and peaceful relationship with the world raised the dwelling experience to a spiritual level. Attaching a full signification to the dwelling by means of a meaningful landscape remained a main theme of Le Corbusier's urban visions, ultimately expressed in the dwelling units of the unités d'habitation. This established the basis of his later adherence to the German debate on town planning, which he often expressed in the polarized emotions of paradise - the life in the garden city - and hell - the modern metropolis (e.g., Le Corbusier 2011: 332).

\section{Edirne and the Ville Contemporaine}

The relationship between the monastery of Ema and the landscape also involves issues of form:

"In the musical landscape of Tuscany I saw a modern city crowning a hill. The noblest silhouette in the landscape, an uninterrupted crown of monks' cells; each cell has a view of the plain, and opens on a lower level on an entirely closed garden. I thought I had never seen such a happy interpretation of a dwelling." (Le Corbusier 1991: 91).

In this later comment about Ema, we find a formal reduction of the city to an architectural entity crowning the hill. The view of the city as a unified formal entity is recognizable in Le Corbusier's 1922 Ville Contemporaine (Passanti 1987, 2008), with its geometric layout crowned by the central skyscrapers (Fig. 8). This is influenced by the focus of the German early twentieth-century town planning debate on the overall form of the city, conceptualized by Theodor Fischer in the idea of the Stadtkrone (city crown), later propagated by Bruno Taut's Die Städtkrone (1919): the city crowned by a dominant building with symbolic meaning capable of giving cohesion to the overall image of the city, taking the medieval city dominated by its cathedral as a referent to the modern city conceived as a collective manifestation of an organic society. ${ }^{1}$ Moreover, in

\footnotetext{
1 The concept of "organic society" relates here to the distinction introduced by Ferdinand Tönnies's Gemeinschaft und Gesellschaft (1887) between two fundamental types of social relations underlying historical and social change. Gemeinschaft, expressing an "organic life" of communities relates to a lost preindustrial harmonic
}

adopting the image of the archetypal sacred city - a circumscribed space with a symbolic vertical element as in the examples illustrated in Taut's book ${ }^{2}$, a regular grid, dual axes, formal entrances and concentric hierarchy - the Ville Contemporaine encapsulates a secularized view of the city as a temple, with obvious links to the ideal society Le Corbusier envisaged (Vidler 1968). Thus, the Ville Contemporaine extends beyond function to include form and meaning: it is a city conceived as a formal entity with reference to the primitive temple for a modern organic society.

Although the comment on the monastery of Ema crowning the hill postdates the Ville Contemporaine, the concept of Stadtkrone and the links between form, organic society and landscape were acquired much sooner. Le Corbusier's focus on the overall form of the city had been triggered by his research into town planning in 1910, which began in Germany with a reading of Camillo Sitte's City Planning According to Artistic Principles (1889), resulting in a manuscript titled $L a$ Construction des villes, which he never published. ${ }^{3} \mathrm{Le}$ Corbusier started by absorbing Sitte's aesthetic approach to the city and his view of the medieval city as a spontaneous expression of an organic society whose archetype was to be found in ancient Greece (Schnoor 2008; Passanti 2008: 28-32). He was then influenced by various discourses built upon Sitte, such as Fischer's. Germany also introduced Le Corbusier to the debate on the garden city and the aesthetic, social and public health issues associated with it, which resurface in the manuscript (2008b: 447). The case of Hellerau, where his brother had joined Emile Jaques-Dalcroze in October 1910, is a good example of how Le Corbusier became familiar with these concerns and with the idea of a renewed society envisaged in the light of a primeval existence in close contact with nature (De Michelis 1990).

In 1908, the announcement of the competition for Gross-Berlin had led to the opening of the Berlin-

culture, as opposed to Gesellschaft, the product of a "mechanical," abstract life of industrial society. The possibility of reinstating a harmonic culture and reattaching a full signification to the city and the dwelling (i.e., of reconciling the existential condition of homeland, or Heimat, and the context of the industrialized metropolis) became a main theme of the sociological and architectural debate on the modern metropolis in the late nineteenth and early twentieth century in Germany.

2 Although Taut's Die Städtkrone (1919) takes the medieval city and society as a model, it includes a set of images of historical city crowns, ranging from Assyrian and Cambodian temples to the Acropolis in Athens and mosques such as Edirne's Selemiye. A second set of images concerns more recent examples, such as Ebenezer Howard's scheme for the garden city, the capitol at Washington and the New York skyscrapers.

3 This article cites the transcript published by Christoph Schnoor (2008: 231-594) 


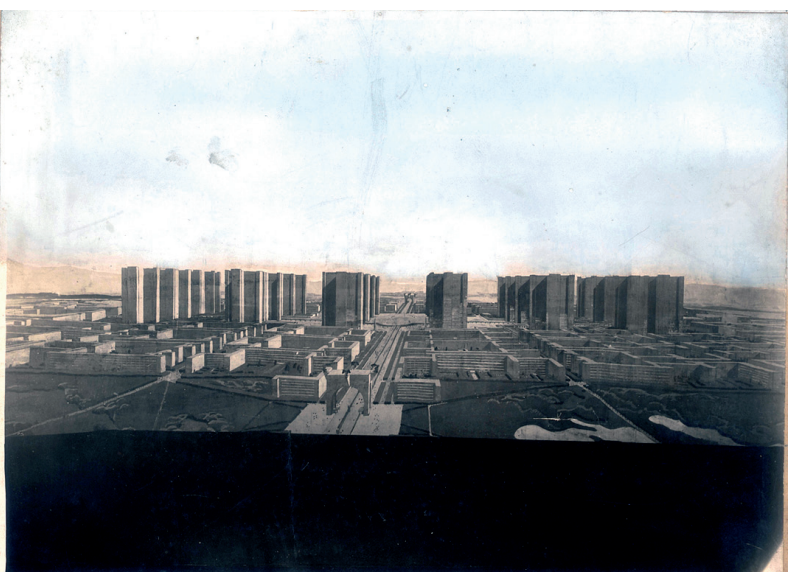

Fig. 8. Le Corbusier. Diorama of the Ville Contemporaine, 1922. OFLC

Charlottenburg Seminar on City Planning (1908-20) founded by Joseph Brix and Felix Genzmer. The seminar placed an emphasis on the city as a whole, and developed to include the visual connection with the surrounding landscape, introducing the discussion in terms of the overall silhouette of the city as a unified object in the landscape (Collins G. R., Collins C. C. 1986: 107-110). ${ }^{4}$ This expanded Fischer's concept of Stadtkrone, also giving rise to concepts such as Stadtlandschaft, or urban landscape, which took on the meaning of city as landscape with Paul SchultzeNaumburg's Kulturarbeiten (1901-1917) (Cohen 2013: 35-36).

Le Corbusier was aware of the Berlin-Charlottenburg Seminar debate. He mentions it in 1912 (2008a: 200) and his interest in the Berlin Exhibition must have led him to the published lectures, widely disseminated in the periodical Städtebauliche Vorträge, gehalten im Seminar für Stadtbau an der Kgl. Technischen Hochschule zu Berlin (1908-1920) early in 1910. Moreover, he had personal contact with several figures associated with this debate, such as Fischer and Peter Behrens. Soon after his arrival in Germany, he attempted to work with Fischer, whose interest in historical cities crowned by meaningful urban structures reflected this focus on the city as a formal entity. Behrens, with whom Le Corbusier worked between November 1910 and April 1911, evokes the same concept in 1912 when arguing in the daily Berliner Morgenpost for the role of skyscrapers in making the overall view of the large horizontal city of Berlin an entity "graspable as an architectural image" (cited in Passanti 1987: 55).

In his manuscript, Le Corbusier (2008b: 469) discussed the city of Breisach on the Rhine (Fig. 9) as an

\footnotetext{
4 I thank Francesco Passanti for pointing out the BerlinCharlottenburg Seminar on City Planning.
}

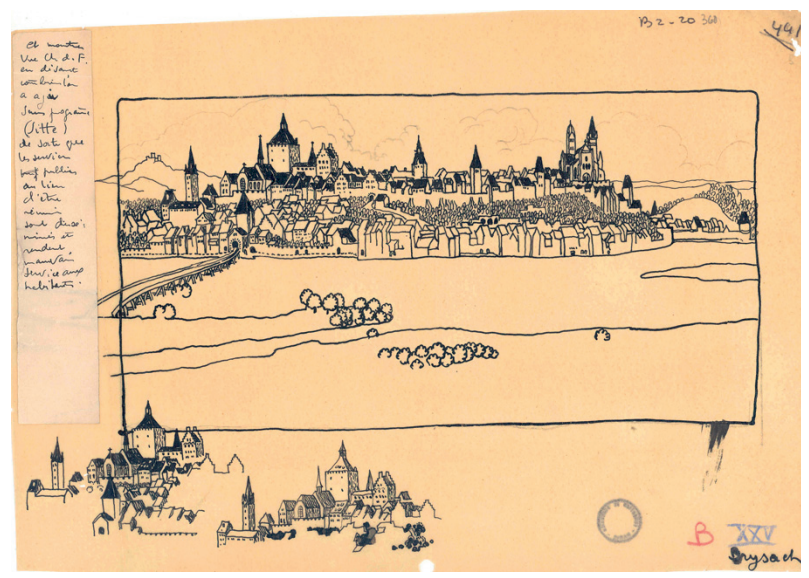

Fig. 9. Le Corbusier. Breisach in the Rhine, 1910. CFLC

example of a hierarchical combination of all the parts of the city in a unity (a Stadtkrone) attained through the "harmonious grouping" of the public buildings around a town square on top of a hill, seeing it as a spontaneous expression of the Middle Ages. The focus on the city as a formal entity also resurfaces in his 1912 assertion (2008a: 181) that garden cities need "to be beautiful as a whole [emphasis by Le Corbusier] and to be harmonious, built in a unique style." Moreover, he expressed ideas associated with the concept Stadtlandschaft when claiming that cities that comply with the topography enrich and enhance the landscape, preserving "the flavour and interest of a natural creation" (2008b: 303-304).

Le Corbusier's visit to Edirne (Adrianople), his first stop in Turkey during the 1911 journey to the East, exemplifies how he looked at the city as a formal entity to be implied by the place, forming a unity with the surrounding landscape.

Edirne is a city in a plain bounded by distant mountains with the Selimiye mosque rising on one summit dominating its silhouette. Le Corbusier (2007: 72, 2002: 58) compared the city to a swelling on the vast plateau, resolved in the mosque's dome. Two aspects of his comments are of note: the focus on the overall form of the city, synthesized in the vertical thrust of its silhouette, and the comprehensive reading of city and landscape as a unified entity. In a letter to his mentor William Ritter (2014: 201), he returns to this comprehensive reading of Edirne, its crowning mosque and surrounding landscape, referring to the mosque as a tiara synthesizing the landscape, and considering it in the light of modern urban design:

“... we recognized in this tiara the sovereign right of being the inconceivable poetic synthesis of this yellow plain bordered by the blue Balkans 
... Civilization will come ... the skyscraper will triumph..."

This clarifies the parallel between Edirne and the Ville Contemporaine: Edirne is depicted as an overall form with a pyramidal silhouette, similar to the Ville Contemporaine; both are crowned by symbolic buildings (the mosque and the skyscrapers); and both rise up from a plain bordered by mountains, enriching and enhancing the landscape, to use his words. In short, the overall design of the Ville Contemporaine is latent in Le Corbusier's 1911 reading of Edirne as a formal unity of city and landscape.

In paralleling both landscapes, however, we encounter a problem of meaning. It may be argued that the distant mountains in the diorama of the Ville Contemporaine have the operative role commonly found in landscape representation of defining a limit for the space which is represented. However, as we have seen, Le Corbusier invested the landscape of Galluzzo with meaning, considering the undulating plain bordered by the Apennines as an ideal landscape. In addition, between the trip to Tuscany and the visit to Edirne the myth of an original Mediterranean existence had evolved into something deeper. Le Corbusier had been exposed to nineteenth-century idealism and its pantheistic doctrines through authors such as Edouard Schuré (Rabaça 2015), acquiring several key notions that would frame his thinking: the view of art and architecture as an expression of a particular people and their life as a whole, and thus dependent on specificities such as geography; a teleological view of history according to which historical destiny is fulfilled by recovering an original, pantheistic existence; the view of nature as an expression of divine immanence.

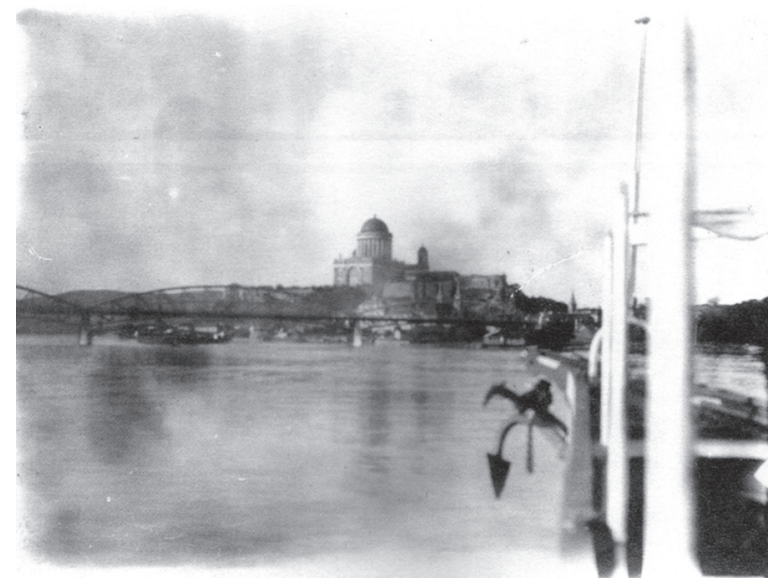

Fig. 10. Le Corbusier. Cathedral of Saint-Adalbert crowning the city of Esztergom, 1911. (Bibliothèque de La Chaux-deFonds, Fonds Le Corbusier). @FLC
This association between the unity of city and landscape and the view of nature as the embodiment of the divine surfaces at the beginning of his journey to the East while crossing the Balkans (Le Corbusier 2007: 36-49): the "eternal movement" of the Danube and the vast plains around it are seen to proclaim the immutability of all things, i.e., as imbued with the divine; Budapest, which he disliked, is described as a leprous sore on the body of a goddess; the fortress of Pressburg (Bratislava) is described as a cubic form set upon the sphinx like a rock - a Stadtkrone - as if the fortress was an extension of nature; in Esztergom (Fig. 10), the cube and dome of the cathedral of Saint-Adalbert, crowning the city, are described as an offering on the altar of the rising mountains; in Negotin (Fig. 11), he depicts the twenty-six square towers along the meandering river as a powerful composition emerging from it - an image later explored in the Buenos Aires skyscrapers, as many have pointed out, recalling Behrens's comments on modern skyscrapers.

These comments clarify the numinous quality of the union of city and landscape that we sense in his description of Edirne and its plain bordered by the blue Balkans. Significantly, the image of a plain bounded by distant mountains had become a paradigmatic representation of a mythical landscape both in painting and literature. Several sources known to Le Corbusier may be cited. In painting, a significant example is Puvis de Chavannes, who had become his favourite nineteenth-century artist during his time in Paris, and who explored this image in works such as the Vie pastorale de Sainte Geneviève (Fig. 12), a postcard of which decorated Le Corbusier's room (Brooks 1997: 176). In literature, one major example is Ritter, who viewed Slovakia and the Balkans through an idealised association between landscape and peasant life and art, des-

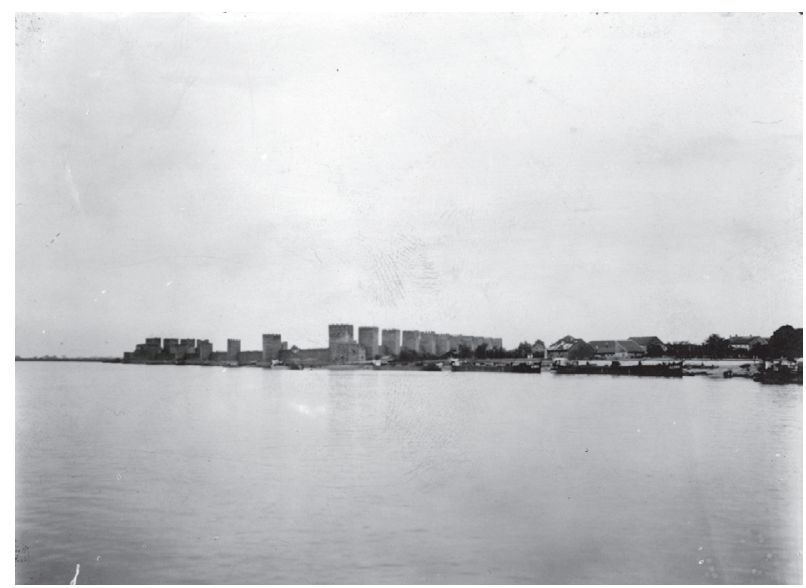

Fig. 11. Le Corbusier. Fortress of Negotin, 1911. CFLC 

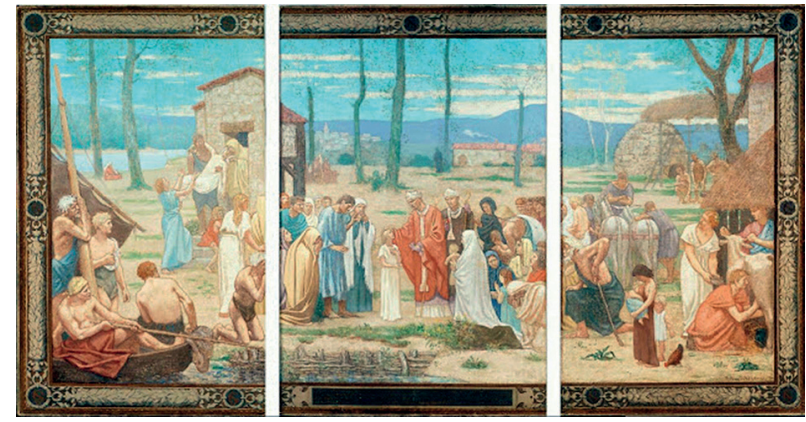

Fig. 12. Pierre Puvis de Chavannes. Vie pastorale de Sainte Geneviève, 1879. @Norton Simon Museum

cribing them as "these mountainous countries where the plain decides unexpectedly to become mountain, and where characters are in harmony with the slow energy of the foregrounds and the depth of horizons" (Ritter 1910: 8). Other examples may be added, such as Schuré's description of Jerusalem (1907: 320-322) as a city silhouette dominated by two huge domes (the Saint-Sepulchre and the Dome of the Rock) and bounded by the horizontal line of the ridge of the Moab; or even Jacob Burckhardt (cited in Riat 1900: 104-105), who praised the contrast between the architecture of Italian gardens and nature in the wild, composed of a plain dominated by mountains.

These sources, framed by the idealistic association between an original existence and a mythical Mediterranean landscape, provided Le Corbusier with a paradigmatic image of this primeval existence. For him, a plain bounded by mountains was now an existential landscape reflecting pantheistic union with the world. Jean-Louis Cohen (2013:30) has recently noted that Le Corbusier transformed landscapes that moved him into landscape-types: primal scenes visually and verbally recorded in his memory to be reused in his later works. Edirne, read as unity of city and landscape, represents perhaps the first of these primal scenes, enriched soon after by the Athenian Acropolis rising upon the Attic plain framed by the sea and the bounding mountains of Hymettos, Pentelikon and Parnes. Le Corbusier's later exploration of this primal scene in the Ville Contemporaine reveals his attempt to create a modern city for a renewed organic society and a symbol of pantheistic union of city and landscape.

\section{Istanbul and the Athens Charter}

Many have noted that Le Corbusier's sojourn in Istanbul was marked by his effort to comprehend the city and its architecture. Unity of city and landscape continued to inform his approach. He strategically planned his arrival by boat to provide him with a panoramic experience of the unfolding city and landscape (Le Corbusier 2007: 88-89), as described at length in the literature of the Grand Tour. Unlike Edirne, the complexity of Istanbul could not be synthesized through the concept of Stadtkrone, requiring twenty days of hard work for the secrets of the city to be revealed (Le Corbusier 2007: 217).

Indications of this comprehensive reading can be found in the description of the Hagia Sophia as it unfolds in its strategic location, emerging at the top of the first hill in old Constantinople, dominating the Sea of Marmara, the Bosphorus, Scutari, and the Golden Horn. He comments on the unity between the sea, the landscape, and the city, and sees Pera, Istanbul and Scutary as complementing each other in their dissimilarities, constituting a majestic unity, a trinity (Le Corbusier 2007: 85). ${ }^{5}$ Passanti (2008: 31-33) has shown that the unity of this trinity, read as three complementary parts with different uniform characters, resonates with the notion of "guiding intention" underlying Laugier's precept "order in the detail, tumult in the ensemble," anticipating the aesthetic appeal of the different functional areas which together form the "larger drama" of the Ville Radieuse. When applied to Old Istanbul, Laugier's lesson allows us to understand another step in Le Corbusier's urban visions, one that ultimately leads from the Ville Radieuse to the Athens Charter.

Old Istanbul is dominated by the Hagia Sophia and the main Ottoman mosques built on top of a series of hills that, facing the Golden Horn and Pera, develop along the north side of the ridge that runs from the extremity of the peninsula towards west (Fig.13). The presence of the various mosques aligned with Mecca, rising from the wooden mass of houses and contrasting in scale, form, material and orientation, is still easily felt today, and was certainly even more marked at the beginning of the century. From a distance, the houses and greenery form a homogeneous mass shaped by the topography, from which the mosques emerge, with their vertical thrust and common direction extending the hilltops.

The approach from the Sea of Marmara exposes the promontory occupied by old Istanbul, dominated by the Hagia Sophia. Le Corbusier (2011:380-381) described this strategic location and from his room in Pera had a panoramic view over the northern waterfront, the line of hills, and the mosques. Describing his departure

\footnotetext{
5 Istanbul - which Le Corbusier refers to as the old part of the city - Pera, and Scutari are the three areas of Istanbul united by the sea. An inlet extending from the Bosphorus defines the Golden Horn and divides the European side in two, with old Istanbul to the south and Pera to the north. Scutari lies on the Asian shore of the Bosphorus (see Fig. 13).
} 
from Istanbul $(2007: 144,152)$, he refers to the city as a homogeneous mass of dark wooden houses punctuated by the main mosques on top of the hills, forming a unit facing the horizontal sea. He sees three main elements: the stone dwellings of Allah, the wooden dwellings of the mortals with their flat roofs covered with tiles, and the greenery of the cemeteries and courtyards punctuating the cityscape (Fig. 14). "I have understood," he writes, "I don't believe I shall ever again see such Unity!"

Soon after, thinking of the dichotomy between the dense city of La Chaux-de-Fonds and the surrounding landscape, Le Corbusier (2002: 58) wrote about the necessity of planting large pine trees "around our houses" [emphasis by Le Corbusier]. Later, he argued (1971: 287) that in his Plan Voisin, ancient Parisian districts would be demolished, but ancient churches would be preserved surrounded by greenery; "what could be more charming?" This reflects his 1911 diagrammatic reading of Old Istanbul, presented in Urbanisme (1971: 57-80) as the referent to the ordering principle of the modern city, i.e., of how the modern city could achieve unity through Laugier's precept by being conceived of as a body of classified, standardized organs: a composition rich in contrapuntal elements (tumult in the ensemble) submitted to a guiding intention (order in detail).

In reading the complexity of Old Istanbul through Laugier, Le Corbusier's idea of unity evolved from the Stadtkrone to a body of standardized organs expressing a guiding intention interweaving with greenery. A parallel can be drawn here between Old Istanbul and the Athens Charter. Like the Ottoman mosques, the unités establish a guiding intention through their common direction, self-referential form, scale, independence from the street network and contrast with the interweaving greenery (Fig. 15). Standardization and common direction secure a coherent structure, allowing the city to be experienced as a unity.

While one must keep in mind that the Athens Charter involve problems that vary from new technologies and standardization to function and hygienic requirements, meaning also plays a key role here. The mechanistic aspects of the city, Le Corbusier argues in Urbanisme (1971: 54-55), are to be subsumed in the "soul of the city," which expresses man's "profound feelings". The mechanistic harmonization of the city, he adds, consists of a "unity of intention" that reflects man's sentimental organization. In other words, the common axis of the mosques of Istanbul, which provides a reference for the formulation of the modern city, also concerns symbol and meaning.

Again, meaning resurfaces in his 1911 writings (2007: 104), in which the overpowering drama of the

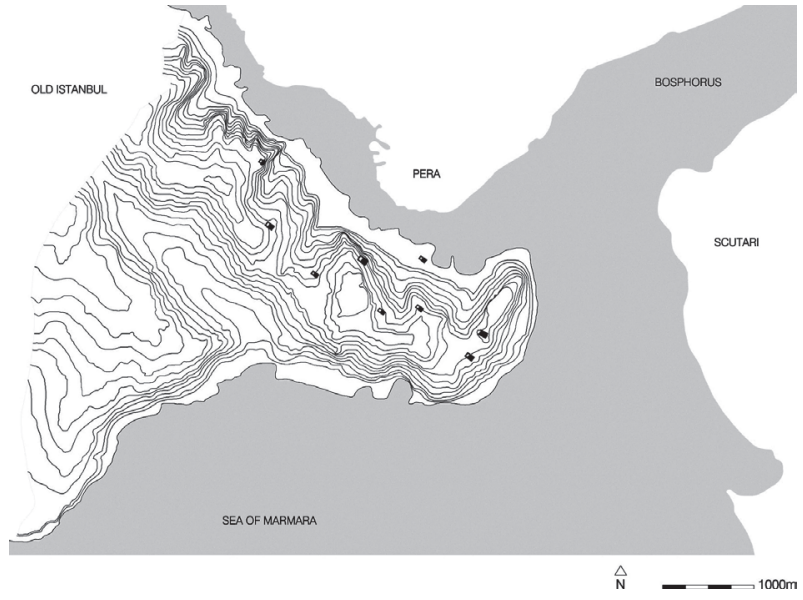

Fig. 13. Topographic plan of old Istanbul with Hagia Sophia (on the right) and the main Ottoman mosques upon the northern hills facing Pera. Cauthor

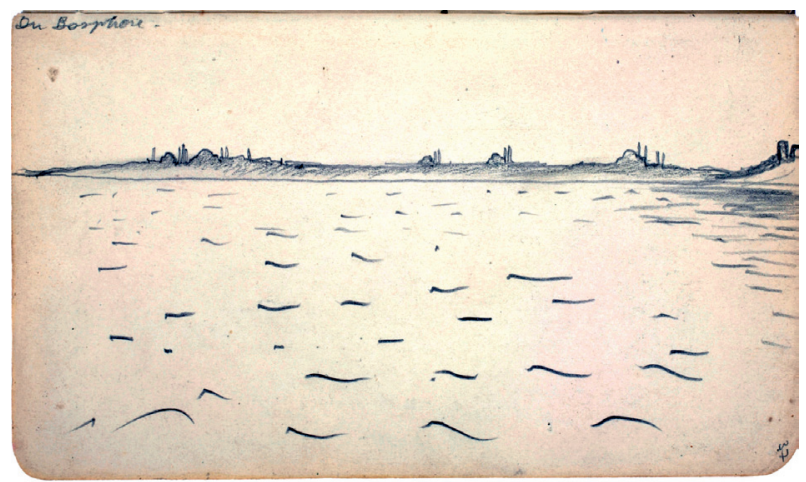

Fig. 14. Le Corbusier. Istanbul seen from the sea. Sketchbook 3 of the journey to the East, 1911. @FLC

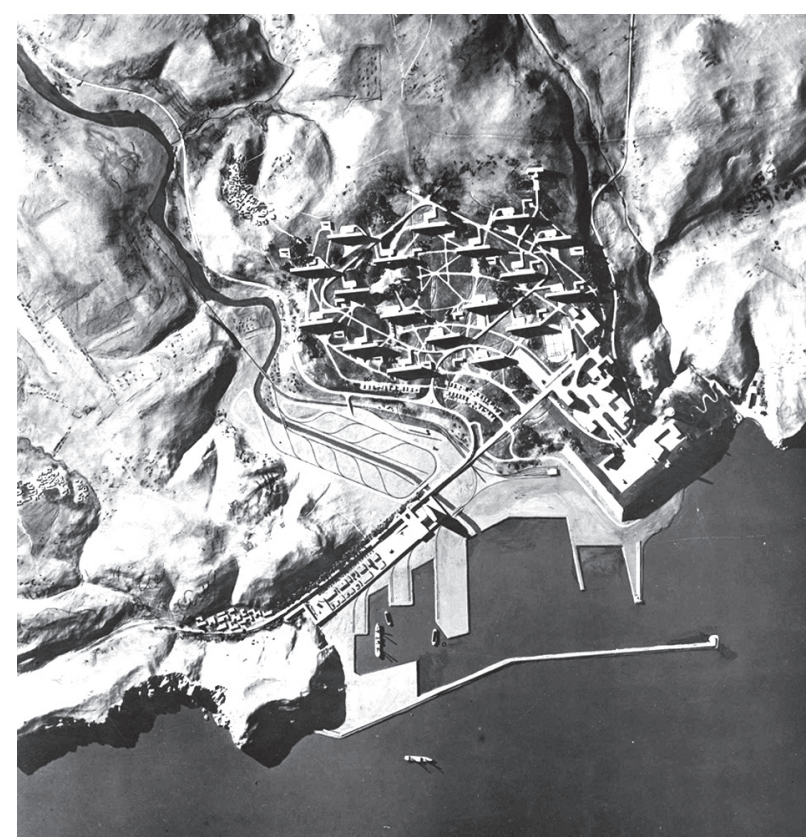

Fig. 15. Le Corbusier. Plan for Nemours, 1934. Model. @FLC 
unified action of the Ottoman mosques is something more than a formal, structuring principle. It is a sign of the Turkish soul and faith: "The orientation of the axis of every mosque on Moslem soil towards the black stone of the Kaaba is an awe-inspiring symbol of the unity of faith." The reference to "unity of faith" relates here to a pantheistic existence which, according to the teleological view of history in the nineteenth-century idealist thinking to which Le Corbusier was exposed, traversed history and, if retrieved, would allow for a unified modern society to emerge (Rabaça 2015). Significantly, reference to pagan solar religion, one of the symbols of this pantheistic doctrine, may be also identified in Le Corbusier's words (2007: 96):

"At this very moment there are millions of them [Muslims] throughout Islam facing toward the black Kaaba in Mecca with open arms. At the moment when all foreheads radiate the same adoration, boundless horizons bite into the bloody disc of the sun."

The idea of pantheistic union with the world and the view of the city as a temple were now objectified in the relationship between the single axis of the mosques and the cosmic, natural world, just as Le Corbusier would read the axis of the Parthenon as a symbol of cosmic and pantheistic unity of architecture, nature and original Greek existence (Le Corbusier 2008c: 231-251). In condensing the diagrammatic reading of Old Istanbul to a dialogue between unités and the natural world, the Athens Charter ascribes a territorial scale to the alliance between city and landscape where solar orientation goes beyond health requirements to attach a full signification to the city. This extends to the dwelling, for the directing of each of the dwellings - which Le Corbusier repeatedly compared to a temple - towards

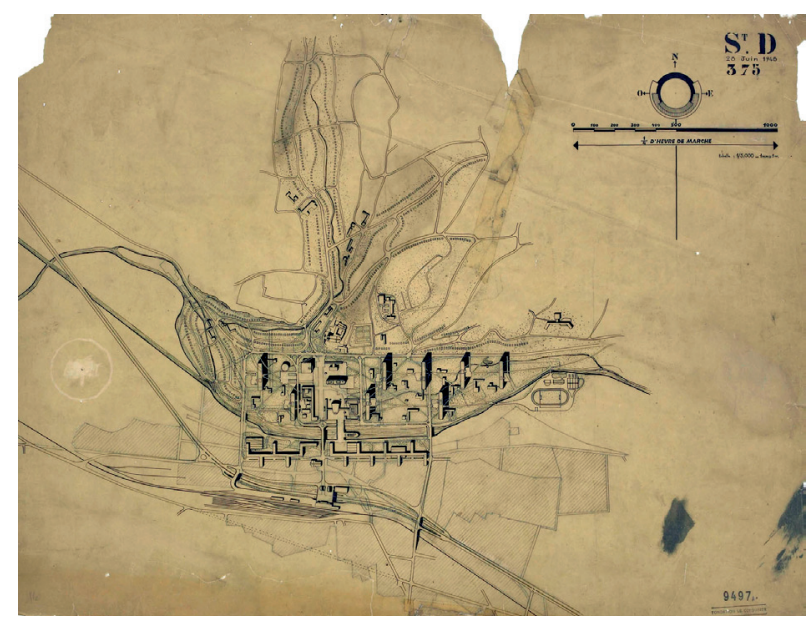

Fig. 16. Le Corbusier. Plan for the reconstruction of Saint-Dié, 1945. CFLC the rising and setting sun allows the pantheistic realm of nature to emerge, enacting the primeval existence that he had sensed in the cells of the monastery of Ema.

Tafuri (1987) was right in arguing that Le Corbusier saw in Muslim culture a primeval mode of existence which the "Plan Obus" is called upon to recover. The links between Le Corbusier's 1911 reading of Old Istanbul, Urbanisme and the Athens Charter show the roots and endurance of his attempt, and how it involved issues of form, symbol and meaning. Edirne represented a landscape-type later explored in the Ville Contemporaine. Through classification and axial ordering, Old Istanbul provided him with a second landscape-type, ultimately leading to the Athens Charter urban scheme.

\section{The tapis vert and the modern utopia of dwelling}

The lesson of Old Istanbul provided Le Corbusier with a model to solve the dichotomy between city and nature. Through classification, the return to nature underlying the garden city could be solved within the city itself. This is first manifested in the Ville Contemporaine and Ville Radieuse. The Ville Contemporaine distinguishes between buildings and greenery interweaving both and reconciling natural spaces with the increase of density. Public space distinguishes between central square, parks, and mechanical circulation, greenery spreading all over the city. Yet, the concentric scheme generates a self-contained form set against the natural surroundings. The Ville Radieuse loses this formal cohesion, although geometry still distinguishes between city and natural surroundings. Public spaces do not differ significantly from those of the Ville Contemporaine, except for the more conventional scheme generated by the alignment of the immeuble-villas, which is now abandoned.

It is in the Athens Charter that the shift from formal cohesion to guiding intention is fully expressed (Figs 16, 17). Standardization and common direction secure unity of form, unity with nature being achieved through a radical elaboration of the concept of Stadtlandschaft - city as landscape: the zoning principle shifts from geometry to the compliance with nature (e.g. Nemours), while the limits between city and natural surroundings are diluted. The outer spaces where human activities are expected to take place are essentially reduced to public parks and the civic centre. Parks now form a continuous surface. The principle seems to be reversed: buildings are disposed within a park, rather than parks between buildings, becoming impossible to know where parks end and the surrounding nature begins. The continuous tapis vert passing underneath 


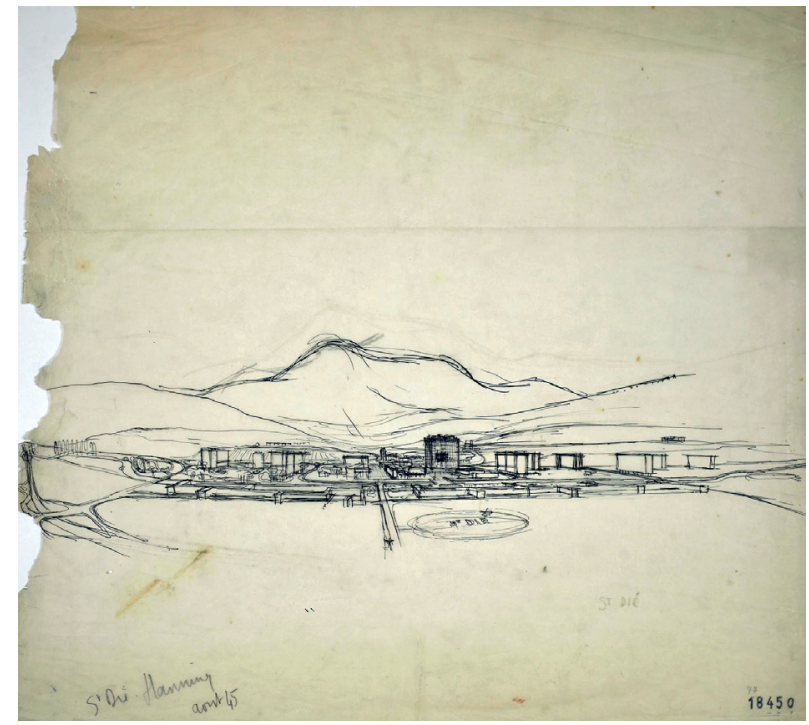

Fig. 17. Le Corbusier. Plan for the reconstruction of Saint-Dié, 1945. OFLC

the housing blocks in the boundless city claims for the unity of city and natural surroundings. Whereas in the Plan Obus nature remains a matter of contemplation for the worshipers of nature (Le Corbusier 1964: 233) the tapis vert is meant to be inhabited, transforming the earth into the "house of man," to use an expression of the Saint-Simonian utopian movement (Picon 2013). Through the coalescence with a meaningful nature, the tapis vert provides an existential living experience in the modern city and the place for collective expression of a renewed society.

The process of gradual dismemberment of the traditional city and its public spaces and its replacement by the boundless tapis vert is, as largely acknowledged, an answer to functional, social, technological and hygienic concerns. The intent here has been to show that Le Corbusier's urban visions also constitute an attempt to realize an "ultimately impossible utopia of dwelling" (Dal Co 1990), that is, to create a modern city for an organic modern society, recovering the harmonic life of the past that industrialization had brought to an end. This utopia had gained particular expression in the German sociological debate around the question of the modern metropolis in the late nineteenth century, having informed the core of the German architectural culture that Le Corbusier encountered in Germany in 1910 and 1911. Sitte's focus on the medieval town square as a place for collective expression and Fischer's and Taut's Stadtkrone exemplify the extent to which the German debate on urban planning was rooted in this utopia. Their look into the past was framed by the coexistence of an idealized vision of preindustrial organic societies and faith in the future and progress of civilization. Their search, and belief, lied in the reestablishment of a Heimat (a homeland), i.e., in a still attainable sense of rootedness and existential condition within the life experience of the Grossstadt. For Le Corbusier, this debate was laid upon Rousseau's notion of origins and the nineteenth-century idealistic vision of an original existence, having provided a fertile ground for his urban thoughts during the journey to the East and for his lifelong urban explorations.

\section{References}

Brooks, H. A. 1997. Le Corbusier's formative years: CharlesEdouard Jeanneret at La Chaux-de-Fonds. Chicago: University of Chicago Press.

Cohen, J.-L. 2013. In the cause of landscape, in J.-L. Cohen (Ed.). Le Corbusier: an atlas of modern landscapes. London: Thames \& Hudson, 23-47.

Collins, G. R.; Collins, C. C. 1986. Camillo Sitte: the birth of modern city planning. New York: Dover Publications.

Dal Co, F. 1990. Dwelling and the "places" of modernity, in Architecture and thought. German architecture culture 1880-1920. New York: Rizzoli, 12-81.

De Michelis, M. 1990. Modernity and reform, Heinrich Tessenow and the Institute Dalcroze at Hellerau, Perspecta 26: 143-170. http://dx.doi.org/10.2307/1567159

FLC. Fondation Le Corbusier. Paris, France.

Le Corbusier. 2008a. A study of the decorative art movement in Germany, in M. Kries (Ed.). Le Corbusier: a study of the decorative art movement in Germany. Weil am Rhein: Vitra Design Museum, 137-206. First published in 1912 as Étude sur le mouvement d'art décoratif en Allemagne.

Le Corbusier. 2007. Journey to the East. (Rev. Ed.). Cambridge, Massachusetts: MIT Press. First published in 1966 as Le Voyage d'Orient.

Le Corbusier. 2008b. La Construction des villes, in C. Schnoor (Ed.). Le Corbusier, La Construction des Villes, CharlesEdouard Jeanneret's erstes städtebauliches Traktat von 1910/1911. Zurich: Gta Verlag, 231-627.

Le Corbusier. 2011. Le Corbusier, correspondance: Lettres à la famille 1900-1925, in R. Baudouï and A. Dercelles (Eds.). Paris: Fondation Le Corbusier, Infolio éditions.

Le Corbusier. 2014. Le Corbusier, William Ritter. Correspondance croisée 1910-1955, in M.-J. Dumont (Ed.). Paris: Éditions du Linteau.

Le Corbusier. 2002. Le Corbusier, Voyage d'Orient, Carnets. Milan, Paris: Electa Architecture, Fondation Le Corbusier.

Le Corbusier. 1991. Precisions on the present state of architecture and city planning: with an American prologue, a Brazilian corollary followed by The temperature of Paris and The atmosphere of Moscow. Cambridge, Massachusetts: MIT Press. First published in 1930 as Précisions sur un état présent de l'architecture et de l'urbanisme.

Le Corbusier. 1971. The city of tomorrow and its planning. London: The Architectural Press. First published in 1925 as Urbanisme.

Le Corbusier. 1964. The radiant city. New York: Orion. First published in 1935 as La Ville Radieuse.

Le Corbusier. 2008c. Toward an architecture. London: Frances Lincoln. First published in 1923 as Vers une architecture. 
Passanti, F. 2008. The aesthetic dimension in Le Corbusier's urban planning, in E. Munford, H. Sarkis, N. Turan (Eds.). Josep Lluís Sert: The Architect of Urban Design, 1953-1969. New Haven, London: Yale University Press, 25-37.

Passanti, F. 1987. The skyscrapers of the Ville Contemporaine, Assemblage 4: 52-65. http://dx.doi.org/10.2307/3171035

Passanti, F. 2010. Toscane, in M. Talamona (Ed.). L'Italie de Le Corbusier. XVe Rencontres de la Fondation Le Corbusier. Paris: Fondation Le Corbusier, Éditions de La Villete, 18-27.

Petit, J. 1970. Le Corbusier lui-même. Geneva: Éditions Rousseau.

Picon, A. 2013. Learning from utopia, Journal of Architectural Education (67): 17-23. http://dx.doi.org/10.1080/10464883.2013.767120

Rabaça, A. 2015. The philosophical framework of Le Corbusier's education: Schuré and German idealism, in J. Torres Cueco (Ed.). Le Corbusier, 50 years later. Valencia: Editorial Universitat Politècnica de València. http://dx.doi.org/10.4995/LC2015.2015.671

Riat, G. 1900. L'Art des jardins. Paris: Société Française d'éditions d'art.

Ritter, W. 1910. L'Entêtement slovaque. Paris: Bibliothèque de l'Occident.

Schnoor, C. 2008. Le Corbusier, La Construction des villes, Charles-Edouard Jeanneret's erstes städtebauliches Traktat von 1910/1911. Zurich: Gta Verlag.

Schuré, E. 1907. Sanctuaires d'Orient: Égypte, Grèce, Palestine. $4^{\text {th }}$ ed. Paris: Librairie académique Perrin et Cie.

Serenyi, P. 1967. Le Corbusier, Fourier, and the Monastery of Ema, The Art Bulletin 49(4): 277-286. http://dx.doi.org/10.1080/00043079.1967.10788665

Tafuri, M. 1987. 'Machine et memoire': the city in the work of Le Corbusier, in H. A. Brooks (Ed.). Le Corbusier: the Garland essays. New York: Garland Publishing, 203-218.

Taut, B. 1919. Die Städtkrone. Jena: Eugen Diederichs.

Tönnies, F. 1887. Gemeinschaft und Gesellschaft. Abhandlung des Communismus und des Socialismus als Empirischer Culturformen . Leipzig: Fues's Verlag.

Vidler, A. 1968. The idea of unity and Le Corbusier's urban form, Architects' Year Book XII: 225-237.

\section{ARMANDO RABAÇA}

is an architect and professor of Design Studio and Architectural Theory at the Department of Architecture of the University of Coimbra, where he has taught since 1998. He holds a PhD in Architecture from the University of Coimbra with a thesis about Le Corbusier's formative years. He is author of the book Entre o Espaço e a Paisagem (Coimbra: edarq, 2011), has contributed to a number of architectural periodicals, and is currently preparing the edition of a book about Le Corbusier. His main research interests are nineteenth-century architectural theory and early twentieth-century architecture. 